\title{
GOOD CORPORATE GOVERNANCE AND EARNINGS MANAGEMENT IN INDONESIA
}

\author{
Irma Paramita Sofia ${ }^{1 *}$, Verliani Dasmaran ${ }^{2}$ \\ Accounting Study Program, Universitas Pembangunan Jaya ${ }^{1}$ \\ Accounting Study Program, Universitas Mathla'ul Anwar Banten ${ }^{2}$ \\ *Corresponding Author: irma.paramita@upj.ac.id
}

\begin{tabular}{l}
\hline ARTICLE INFO \\
\hline Article History: \\
Received: December 11, 2020 \\
Revised: January 26, 2021 \\
Published Online: February 19, 2021 \\
Keywords: \\
Earnings Management, Audit Quality, \\
Audit Committee, Corporate \\
Governance, Manufacturing \\
Company.
\end{tabular}

How to cite:

Sofia, I. P., Dasmaran, V. (2021). Good Corporate Governance and Earnings Management in Indonesia. International Journal of Digital Entrepreneurship and Business (IDEB), $2(1), 49-57$.

\begin{abstract}
The purpose of this study was to analyze the effect of audit quality and audit committee on earnings management. The research population is manufacturing companies indexed on the Indonesia Stock Exchange (BEI) in the 2017-2019 period. The sample selection method used was purposive sampling. From population of 180 manufacturing companies, and by selecting certain criteria, a sample of 104 manufacturing companies was obtained. Hypothesis testing is performed using multiple linear regression using statistical software SPSS Version 26. The results of this study confirm that partially, audit quality affects earnings management and audit committee also affects earnings management. Then, hypothesis testing is also carried out simultaneously, and the result is that the quality of the audit and audit committee also affects earnings management. The practical implication of this research is that the quality of the audit and the audit committee can be a reference for investors that can be used as material for consideration in making decisions when investing in potential companies.
\end{abstract}

\section{INTRODUCTION}

In carrying out its activities, the company aims to be able to get returns from its investment activities. All companies do not want to experience losses, all companies in their activities certainly want to get the maximum benefit. Profits obtained in one period will be reported in the Financial Statements. The presentation of financial statements is the final estuary of financial accounting, where there is an important point of view in financial accounting, namely valuation/measurement through making a balance sheet or making a profit and loss (income statement). Information regarding financial statements can be said to be relevant, if the presentation can provide additional information directly to the parties who use it. In addition to providing information related to company finances, financial statements will provide guidelines for investors in making business decisions. However, sometimes external parties are not provided with information about the actual financial reports, causing differences in information between internal and external parties (Sulistyanto, 2008). Many companies in Indonesia, in managing the preparation of their financial statements, practice earnings management, to change transactions or other activities related to financial statements with the aim of giving certain impressions to influence the actions of users of financial statements (Healy, 1985).

According to Soemarsono (2010) profit is the excess of expenses over income in connection with the company's business activities. Therefore, expenses and income are often used as management targets to control profits. In order to measure and determine the occurrence of earnings management practices, there are ways to detect earnings management practices that occur in the company. There is research 
that has been done on earnings management, most of which link earnings management to the company's performance.

The case of fraud in accounting in the business world related to financial statements is increasingly developing, especially in companies that go public both domestically and abroad, so that it can attract serious attention from stakeholders. There is a phenomenon that occurs regarding the practice of earnings management that occurs in Indonesia, such as in PT Garuda Indonesia in 2018 which recorded receivables as income so as to make the financial statements look healthy but actually suffered a loss of Rp. 1.66 trillion. Information about earnings is information that can be said to be important to be used as a basis for decision making by investors who want to invest, but information about this profit is often the target of engineering by company management to maximize its interests, so it can harm external parties such as investors, creditors, government, and others (Christiani \& Nugrahanti, 2014). In other information, profit is also often misused by company management for self or group retirement in maximizing satisfaction.

In assessing the fairness of a financial report, an auditor is needed who can detect the possibility of material misstatement that occurs in the financial statements, whether it is due to an error or fraud was committed. High quality audits can be said to be able to prevent the existence of earnings management practices. Apart from audit quality, another factor that can prevent earnings management is the audit committee. In order for the practice of earnings management to be reduced or minimized, an audit committee was formed. The audit committee within a company will play a role in being able to supervise the management of the company so that it is better by processing financial information such as financial reports so that it can help management in taking action (Dwikusumowati \& Nur Rahardjo, 2013). The study re-tested the earnings management variable because there were still inconsistencies in the test results from previous researchers (D. P. Sari, 2018; Sarwinda \& Afriyenti, 2015).

\section{LITRATURE REVIEW}

\section{Agency Theory}

Agency theory describes a meeting or cooperation between the company owner (principal) and the manager of a company (agent) who has a relationship on a predetermined or contractual agreement. According to (Scott, 2009) agency theory is the development of a theory that studies a contract or agreement in which managers (agents) serve or perform work on behalf of the owner of a company (principal) when certain goals or their desires are contradictory or not, there will be a conflict.

A company whose capital consists of shares, investors or shareholders can be said to be the owner of the company (principal) and for the Chief Executive Officer (CEO), namely as an agent of a party acting in accordance with the interests of a principal. The principal party will be motivated to enter into a contract to be able to prosper itself with the profitability of a company which is expected to always increase. Agency theory has an assumption or assumption that each of the individuals is solely motivated by their own interests so that it will create a conflict of interest between the agent and principal of a company (Scott, 2009). The practice of earnings management can be explained by agency theory, namely as a company manager (agent) who makes the financial statements of a company morally have a responsibility to optimize a company's profits or profits for the principal through the company's earnings report. Earnings management itself uses a theoretical approach, namely agency theory related to contracts or relationships between members in the company, especially the relationship between company managers (agent) and the relationship between company owners (principal). For this 
agency relationship sometimes causes problems between company managers or shareholders. Conflicts that occur are usually due to humans themselves, humans are economic beings who have the nature or willingness to be able to prioritize their own needs. For shareholders as well as company managers, it cannot be denied that sometimes they have different goals and each of their interests wants from the goals of both to be achieved, the consequences that occur can create a conflict of interest.

\section{Earnings Management}

Earnings management is a decision of the company manager to be able to choose certain accounting policies as the method chosen to achieve the goals to be achieved, these objectives can be to increase company profits or to be able to reduce company profits or reduce the level of reported losses. In general, there are two approaches that can be used to detect the behavior of company managers in managing earnings. The first approach is to control the accrual type, where accruals are broadly defined as the portion of items for revenue and also expenses (revenue and expense) on the income statement that are not shown on the cash flow statement. The second approach is a change from the accounting policies used in the company. Sari \& Ahmar (2014) in their research stated that there are various methods to measure earnings management. The Jones model is a model to detect earnings management practices. This model is a model that was first introduced by Jones (1991) which was later developed by Dechow et al. (1995) known as the modified Jones Model. Stubben (2010) introduced the Revenue Discretionary Model on the basis of dissatisfaction with the accrual model that is commonly used today.

\section{Audit Quality}

Definition of audit quality according to De Angelo (1981) is the auditor's expertise in finding major errors in financial statements and reporting material misstatements. One way to reduce the misalignment of information between managers and shareholders is to increase the role of auditors (Mahrani \& Soewarno, 2018). Audit quality is seen as the ability to enhance the quality of the company's financial reporting, with high audit quality it is expected to further increase the confidence of external parties, investors so that it is expected that the market will react positively if the financial statements of a company are audited by qualified auditors.

\section{Audit Committee}

The definition of an Audit Committee according to Tugiman (1995) an audit committee is a group of people selected by a larger group to do certain jobs or to perform special tasks or a number of members of the Board of Commissioners of a client company who are responsible for assisting auditors in maintaining independence from management. So, it can be concluded that the audit committee is a group of people or more who are selected and formed directly by the board of commissioners to be able to assist the duties of the board of commissioners, especially in supervising the process of presenting the company's financial statements so as to produce information about the company's financial statements in accordance with applicable accounting principles and can provide information about the actual condition of the company.

\section{HYPOTHESIS}

\section{The Effect of Audit Quality on Earnings Management}

Audit quality can affect earnings management activities. The higher the audit quality of a company, the less the practice of earning management will be. The higher the quality of the audit, the more it will reduce the practice of earnings management, so that the less likely the management is to practice earnings management which will increase the reliability of information from the company's financial 
statements. High audit quality can be seen from the verification of the reliability of the company's financial statements through the audit opinion issued by Public Accounting Firm. The audit quality used in this study is the proxy for the size of the Public Accounting Firm used by the company. This proxy describes the size of the Big Four and Non-Big Four accounting firms. For the size of the Big Four Public Accounting Firm, it has a big role in the process carried out by the company, which with the size of the Big Four Public Accounting Firm do not dare to commit fraud, and the Big Four Public Accounting Firm can be trusted to become credibility in maintaining the good name of the company. Thus, cheating practices are easier to detect.

According to research conducted by Yunila \& Aryanti (2018) in their research, it states that companies audited by Big Four Public Accounting Firm have lower earnings management practices when compared to companies audited by non-Big Four Public Accounting Firm. Big Four Public Accounting Firm has better resulting audit quality than non-Big Four Public Accounting Firm, so that with good resources they will be able to streamline the audit process carried out by Big Four Public Accounting Firm. High quality and independent audit quality can be a control mechanism for company management so that managers provide reliable financial information, and are free from earnings management. According to research conducted by Simanjuntak et al. (2019) stated that the variable of audit quality has an effect on earnings management. Based on previous theory and research, the researcher formulates the first hypothesis as follows:

\section{$\mathrm{H}_{1}$ : Audit quality affects earnings management.}

\section{The Effect of the Audit Committee on Earnings Management}

The Indonesian Audit Committee Association (IKAI) emphasized that the existence of the audit committee is expected to be able to play a role in improving the quality of internal supervision in the company, and is also expected to be able to optimize the checks and balance mechanism, which is ultimately shown to be able to provide the best protection for shareholders, and also other stakeholders. The Audit Committee can be defined as the party that becomes the liaison between the external auditor and company management so that the audit committee is required to be independent in carrying out its duties. In agency theory, there are costs that are used to prevent conflicts of interest between monitoring costs. The Audit Committee is a form of supervision carried out by the principal towards the agent. The role of the audit committee to be able to help reduce opportunistic actions of management is increasingly important, every company that goes public has been required to have an audit committee.

The audit committee serves as a supervisor, supervisor of the process of making financial reports. The activeness of the audit committee in evaluating the performance of company management and also the internal auditors will have an influence on the practice of earnings management, if the audit committee continuously monitors the performance of company management, management will not have the opportunity to carry out earnings management. Research conducted by Azhar \& Islahuddin (2018), states that earnings management is negatively affected by the activeness of the audit committee. This happens because the audit committee in assisting the supervisory duties of the board of commissioners is able to reduce the level of earnings management practices in the company. Based on the theory and previous research, the researcher formulated the following hypothesis:

\section{$H_{2}$ : The Audit Committee has an effect on Earning Management.}




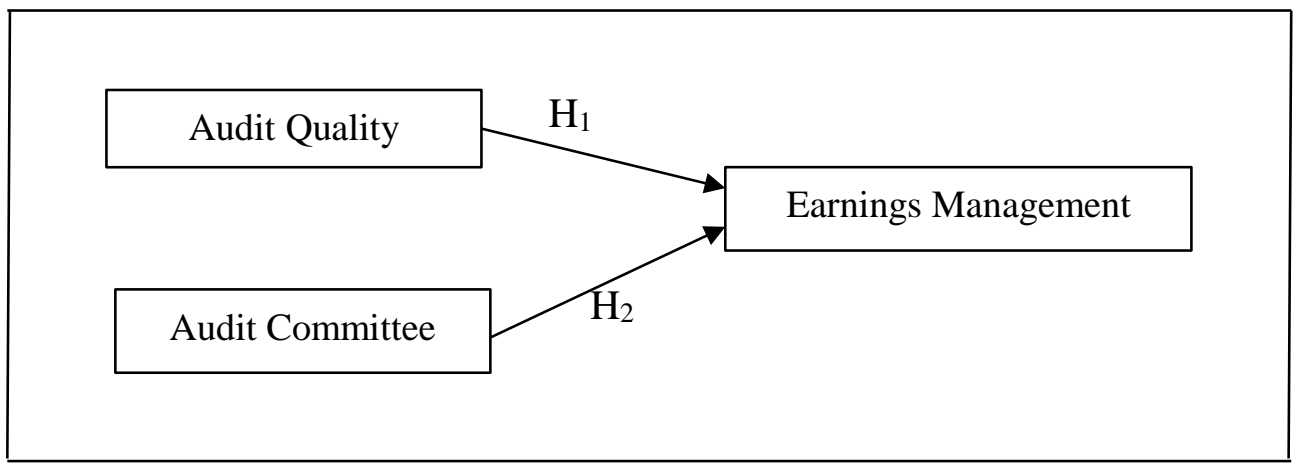

Figure 1: Research Framework

\section{METHOD}

\section{Population and Sample Selection}

The object of this research is earnings management and the factors that can influence it, audit quality, audit committee, company size and cash holding. This research aims to be able to produce empirical evidence, whether there is an effect of audit quality, audit committee, company size and cash holding on earnings management in manufacturing companies listed on the Indonesian Stock Exchange (IDX). Secondary data used is in the form of financial statement data on all manufacturing companies listed on the IDX in 2017-2019. Data obtained from IDX website.

The population of this research is manufacturing companies listed on the IDX for the period 2017 to 2019. The sample is determined using the purposive sampling method, namely sampling based on criteria or considerations to be determined by the researcher. The criteria for companies that will be sampled in this study are:

Table 1: Sample Selection Criteria

\begin{tabular}{|l|c|}
\hline Sample Selection Criteria & Total \\
\hline Manufacturing companies listed on the IDX 2017-2019 & 180 \\
\hline $\begin{array}{l}\text { Manufacturing companies that do not present annual financial reports in rupiah } \\
\text { currency }\end{array}$ & $(29)$ \\
\hline Manufacturing companies that incurred losses & $(34)$ \\
\hline Manufacturing companies that do not have complete financial data availability & $(13)$ \\
\hline Total sample & $\mathbf{1 0 4}$ \\
\hline
\end{tabular}

\section{Dependent Variable}

The dependent variable in this study is earnings management. The measurement of the dependent variable, namely earnings management, in this study uses the Revenue Discretionary Model introduced by Stubben (2010).

\section{Independent Variable}

Independent variables are variables that influence or cause changes or the emergence of independent variables (Sugiyono, 2013). In this study the independent variables that affect earnings management are:

Audit quality is the suitability of audits performed by auditors based on established audit standards (Watkins et al., 2004). The purpose of audit quality is that when the auditor performs the practice of auditing the client's financial statements, he is expected to be able to find errors or violations committed by the client (SPAP, 2011). According to Rahdal (2015), quality measurement uses dummy variables, 
that is, if a company whose financial statements are audited by a Public Accounting Firm affiliated with the Big Four will be given the number 1, and vice versa if the company's financial statements are audited by a non-big four Public Accounting Firm then it will be given the number 0 .

The audit committee variable is calculated using the number of members of the Audit Committee in the company. In this study using quantitative research methods. In this study, it is called quantitative research because the data in this study are in the form of numbers and analysis using statistics (Sugiyono, 2013).

\section{Data analysis method}

The data analysis method used in this study is multiple linear regression analysis, with multiple linear regression equations as follows:

$\mathrm{EM}=\alpha+\beta 1 \mathrm{AQ}+\beta 2 \mathrm{AC}+\mathrm{e}$

Note:

$\begin{array}{llll}E M & =\text { Earnings Management } & \beta 1 & =\text { Audit Quality Regression Coefficient } \\ A Q & =\text { Audit Quality } & \beta 2 & =\text { Audit Committee Regression Coefficient } \\ A C & =\text { Audit Committee } & e & =\text { Error term (Residual Variable) } \\ \alpha & =\text { Constant } & & \end{array}$

\section{RESULT AND DISCUSSION \\ Partial Test Result ( $t$ )}

The $t$ test is used to prove whether there is a significant effect between the independent variables on the dependent variable, with a significance level of 0.05 (5\%). If the significant value is greater $>0.05$ then there is no significant effect between the independent variable on the dependent variable. Meanwhile, if the opposite occurs, namely the significant value is smaller than the number 0.05 , the independent variable has a significant effect on the dependent variable. For decision making the second way, if $t_{\text {count }}>t_{\text {table, }}$ it means that the independent variable has an influence on the dependent variable. Whereas for $\mathrm{T}$ table it can be calculated as follows:

Table 2: t-test Result

\begin{tabular}{|l|l|c|c|c|c|c|}
\hline \multirow{2}{*}{ Model } & \multicolumn{2}{|c|}{$\begin{array}{c}\text { Unstandardized } \\
\text { Coefficients }\end{array}$} & $\begin{array}{c}\text { Standardized } \\
\text { Coefficients }\end{array}$ & T & Sig. \\
\cline { 2 - 7 } \multicolumn{2}{|l|}{ B } & Btd. Error & Beta & & \\
\hline \multirow{2}{*}{1} & (Constant) & .345 & .100 & & 2.059 & .042 \\
\cline { 2 - 7 } & Audit Quality & -.037 & .009 & .266 & 2.735 & .004 \\
\cline { 2 - 7 } & Audit Committee & -.068 & .028 & .345 & 2.775 & .003 \\
\hline
\end{tabular}

Based on Table 2, it can be seen that the value of B for the Audit Quality variable is -0.037 with a significant value of 0.004 . In accordance with the provisions of the first method of decision making, a significant value of less than $0.05(0.004<0.05)$ then $\left(\mathrm{H}_{1}\right)$ is accepted. Based on the provisions of the second method of decision making, if $\mathrm{t}_{\text {count }}>\mathrm{t}_{\text {table }}$ then $\mathrm{H}_{1}$ is accepted. This means that Audit Quality has a negative effect on Earnings Management. This indicates that for every $1 \%$ increase in audit quality, it will decrease Earnings Management by $0.37 \%$.

Based on table 2, it can be seen that the B value for the Audit Committee variable is -0.068 with a significant value of 0.003 . In accordance with the provisions of the first method of decision making, a 
significant value is less than $0.05(0.003<0.05)$ then $\mathrm{H}_{2}$ is accepted. This means that it can be concluded that the audit committee has a negative effect on earnings management. It is stated that every $1 \%$ increase in the Audit Committee, it will decrease the Earnings Management by $0.68 \%$.

Based on Table 2, the regression equation can be obtained as follows:

$$
\mathrm{EM}=0.345-0.004 \mathrm{AQ}-0.003 \mathrm{AC}+0.1 \mathrm{e}
$$

Note:

$$
\begin{aligned}
& E M=\text { Earnings Management } \\
& A Q=\text { Audit Quality } \\
& A C=\text { Audit Committee }
\end{aligned}
$$$$
\alpha=\text { Constant }
$$$$
\beta=\text { Regression Coefficient }
$$$$
e=\text { error term }
$$

\begin{tabular}{|c|c|c|c|c|c|c|}
\hline \multicolumn{7}{|c|}{ ANOVA $^{\mathrm{a}}$} \\
\hline & Model & Sum of Squares & Df & Mean Square & $\mathbf{F}$ & Sig. \\
\hline \multirow[t]{3}{*}{1} & Regression & .031 & 4 & .008 & 3.597 & $.008 \mathrm{~b}$ \\
\hline & Residual & .300 & 139 & .002 & & \\
\hline & Total & .331 & 143 & & & \\
\hline
\end{tabular}

\section{Simultaneous Test $(F)$}

For how to calculate $\mathrm{F}$ table, it can be calculated with the following formula which is below:

Table 3: Simultaneous Test Results (F)

Based on Table 3 above, it can be seen that the results of the Anova test or $F_{\text {count }}$ is 3.597 with a probability of $0.008<0.05$, therefore, the model is accepted. In addition, based on the $F_{\text {table }}$ of 2.44, then $F_{\text {count }}>F_{\text {table }}(3.597>2.44)$, it can be concluded that the regression model of the audit quality variable and the audit committee jointly (simultaneously) has an effect on earnings management.

\section{Effect of Audit Quality on Earnings Management}

In this study, Audit Quality is calculated based on the Public Audit Firm size. This proxy describes the size of the big four and non-big four accounting firms. The test results obtained are that audit quality has an effect on earnings management. This was obtained based on the results of testing the Audit Quality variable in table 2 which obtained a result of 0.004 which can be interpreted as being smaller than 0.05 ; therefore, $\mathrm{H}_{1}$ is accepted. So it can be concluded that the variable of Audit Quality has an effect on Earnings Management in manufacturing companies listed on the Indonesia Stock Exchange.

The results of this study are in line with research previously conducted by Yendrawati (2015) stated that audit quality affects earnings management. This provides an explanation that companies that are audited by Public Audit Firm with high quality big four audits will minimize the possibility of earnings management actions occurring within the company.

\section{The Effect of the Audit Committee on Earnings Management}

In this study, the Audit Committee is calculated based on the number of Audit Committees in the company (Agustia \& Suryani, 2018). The audit committee serves as a supervisor, supervisor of the process of making financial reports. The activeness of the audit committee in evaluating the performance of company management and also the internal auditors will have an influence on the practice of earnings management, if the audit committee continues to supervise the performance of 
company management, then management will not have the opportunity to carry out earnings management.

This research is in line with research conducted by Susanto (2017) which states that earnings management is negatively affected by the activeness of the audit committee. This happens because the audit committee in assisting the supervisory duties of the board of commissioners is able to reduce the level of earnings management practices in the company.

\section{CONCLUSION}

This research was conducted to determine the effect of audit quality, audit committee (independent variable) on earnings management (dependent variable). The analysis was carried out using descriptive statistics and multiple regression using the SPSS version 26 program. Based on the research results, it was found that audit quality variables are calculated based on the Public Audit Firm size. This proxy describes the size of the big four and non-big four accounting firms, which shows the test results that audit quality has a significant effect on earnings management. Audit committee variable which is measured based on the total number of audit committees in the company, which shows the test results that the audit committee has an effect on earnings management. The variables of audit quality and audit committee have a significant effect simultaneously on earnings management.

Based on the research and discussion carried out, as well as the limitations of the research conducted by the author, further research should be conducted with a longer period of years, and use different sample of companies, to better see the period of earnings management that occurs in companies other than manufacturing companies. Researchers can also use a sample of LQ 45 companies listed on the Indonesia Stock Exchange with the 2017-2019 period. For future studies, researchers can try to use proxies or other measuring tools in order to get different results from the current research, which can be more influential than the proxies used in previous studies. Use of other models such as the Jones Model can be used for calculating earnings management for any future research. Use of different independent variables outside of this study that can affect the practice of earnings management, can be used in future researches.

\section{REFERENCES}

Agustia, Y. P., \& Suryani, E. (2018). Pengaruh Ukuran Perusahaan, Umur Perusahaan, Leverage, dan Profitabilitas Terhadap Manajemen Laba Pada Perusahaan Pertambangan yang Terdaftar di Bursa Efek Indonesia. Jurnal Aset (Akuntansi Riset), 10 (1), 63-74.

Azhar, G. A., \& Islahuddin, I. (2018). The Impacts Of Audit Committee's Size, Information Asymmetry, Operating Cash Flow and External Audit Quality on Earnings Management Of Manufacturing Companies in Indonesia. Jurnal Ilmiah Mahasiswa Ekonomi Akuntansi (JIMEKA), 3 (4), 616-624. ISSN 2581-1002.

Christiani, I., \& Nugrahanti, Y. W. (2014). Pengaruh Kualitas Audit Terhadap Manajemen Laba. Jurnal Akuntansi dan Keuangan 16 (1), 52-62.

De Angelo, L. E. (1981). Auditor Size and Audit Quality. Journal of Accounting and Economics, 3(3), 183-199.

Dechow, P. M., Sloan, R. G., \& Sweeny, A.P (1995). Detecting Earnings Management. The Accounting Review, 70 (2), 193-225.

Dwikusumowati, M. Z., \& Nur Rahardjo, S. (2013). Pengaruh Karakteristik Komite Audit dan Karakteristik Perusahaan Terhadap Manajemen Laba. Diponegoro Journal of Accounting, 0, 476490. Retrieved from https://ejournal3.undip.ac.id/index.php/accounting/article/view/5960

Healy, P. M. (1985). The Effect of Bonus Schemes on Accounting Decisions. Journal of Accounting \& Economics, 85-107. 
Jones, J. J. (1991). Earnings Management During Import Relief Investigations. Journal of Accounting Research, 29 (2), 193-228.

Mahrani, M. \& Soewarno, N. (2018). The Effect of Good Corporate Governance Mechanism and Corporate Social Responsibility on Financial Performance with Earnings Management as Mediating Variable. Asian Journal of Accounting Research, 3(1), 41-60.

Rahdal, H. (2015). Pengaruh Ukuran KAP, Ukuran Perusahaan, Arus Kas Bebas, dan Leverage Terhadap Manajemen Laba. Jurnal Universitas Riau, Journal of Management Fekon, 4 (1), 586-599.

Sari, D. P. (2018). Pengaruh Earnings Management, Kebijakan Dividen, Leverage Perusahaan, dan Tax Amnesty Terhadap Return Saham. Skripsi, STIESIA Surabaya.

Sari, N. H. \& Ahmar, N. (2014). Revenue Discretionary Model Pengukuran Manajemen Laba: Berdasarkan Sektor Industri Manufaktur di Bursa Efek Indonesia. Jurnal Akuntansi dan Keuangan, 16(1), 43-51.

Sarwinda, P., \& Afriyenti, M. (2015). Pengaruh Cash Holding, Political Cost, dan Nilai Perusahaan Terhadap Tindakan Perataan Laba (Studi Empiris Pada Perusahaan Manufaktur Yang Terdaftar Di BEI 2009-2013). Proceeding of Seminar Nasional Ekonomi Manajemen dan Akuntansi (SNEMA) Fakultas Ekonomi Universitas Negeri Padang. ISBN: 978-602-17129-5-5.

Scott, W. R. (2009). Financial Accounting Theory. Pearson Prentice Hall.

Simanjuntak, P., Rahayu, S., \& Gowon, M. (2019). The Influence of Information Asymmetry, Audit Committee Effectiveness, and Audit Quality on Earnings Management (Studies on Banking Sector Companies Listed on the Indonesia Stock Exchange in 2013-2017). Journal of Accounting \& Finance Unja , 4 (3), 13-23. doi.org/10.22437/jaku.v4i3.8134

Soemarsono S. R. (2010). Akuntansi Suatu Pengantar, Jakarta: PT Rineka Citra.

SPAP (2011). Standar Profesional Akuntan Publik 2011, No. 1 tentang Standar Audit.

Stubben, S. (2010). Discretionary Revenues as a Measure of Earnings Management. The Accounting Review, 85(2), 695-717. Retrieved February 11, 2021, from http://www.jstor.org/stable/20744146.

Sugiyono (2013). Metode Penelitian Pendidikan Pendekatan Kuantitatif, Kualitatif, dan R \& D. Bandung: Alfabeta.

Sulistyanto, S. (2008). Manajemen Laba:Teori dan Model Empiris. Jakarta: PT Grasindo.

Susanto, I. R. (2017). Faktor-Faktor Yang Mempengaruhi Manajemen Laba Pada Perusahaan Manufaktur di BEI. Jurnal Ilmiah Akuntansi Peradaban, 3 (2), 65-83.

Tugiman (1995). Sekilas Komite Audit, PT. Eresco, Bandung.

Watkins, A. L., Hillison, W., \& Morecroft, S.E. (2004). Audit Quality: A Synthesis of Theory and Empirical Evidence. Journal of Accounting Literature, 23, 153-293.

Yendrawati, R. (2015). Pengaruh Dewan Komisaris Independen, Komite Audit, Kepemilikan Manajerial, dan Kepemilikan Institusional terhadap Manajemen Laba. Universitas Islam Indonesia. Jurnal Entrepreneur dan Entrepreneurship, 4, (1-2).

Yunila, F. \& Aryati., T. (2018). Pengaruh Perencanaan Pajak dan Pajak Tangguhan terhadap Manajemen Laba dengan Kualitas Audit sebagai Variabel Moderasi. Seminar Nasional Cendikiawan: Universitas Trisakti. 